\title{
Los palacios de Pedro I. La arquitectura al servicio del poder
}

\author{
Antonio Almagro \\ Laboratorio de Arqueología y Arquitectura de la Ciudad (LAAC) \\ Escuela de Estudios Árabes, CSIC, Granada \\ aalmagro@eea.csic.es
}

\section{RESUMEN}

El programa arquitectónico palatino desarrollado por Pedro I en el tercer cuarto del siglo XIV constituye un claro ejemplo del uso de la arquitectura como medio de manifestación del poder. Los palacios de Astudillo, Tordesillas, Carmona y Sevilla presentan una serie de características comunes que nos permiten vislumbrar el uso de formas y espacios con funciones claramente relacionadas con la visualización del soberano dentro de un marco adecuado para su exaltación delante de sus súbditos. El Alcázar de Sevilla constituye la culminación de este programa con las más sofisticadas soluciones.

Palabras clave: Arquitectura palatina, Pedro I, portadas, qubba, Tordesillas, Astudillo, Carmona, Sevilla.

\section{The palaces of Pedro I. The architecture at the Service of Power}

\begin{abstract}
The palatine architectural program developed by Pedro I in the third quarter of the 14th century is a clear example of the use of architecture as a means of demonstration of power. The palaces of Tordesillas, Astudillo, Carmona and Seville presents a series of common characteristics that allow us to envision the use of forms and spaces with functions clearly related to the display of the sovereign within an adequate framework for their exaltation in front of his subjects. The Alcazar of Seville is the culmination of this program with the most sophisticated solutions.
\end{abstract}

Key words: Palatine architecture, Pedro I, facades, qubba, Tordesillas, Astudillo, Carmona, Seville. 
En todos los tiempos y culturas la arquitectura ha servido para proporcionar un marco protocolario a las actividades del poder y como forma de expresión del mismo por parte de quienes lo han ostentado. Normalmente, las construcciones realizadas por un determinado personaje o soberano obedecen a programas o modelos que constituían referentes de fácil interpretación por parte de la población, bien en su conjunto, bien a través de algunos de sus elementos que estaban directamente relacionados con la simbología del poder. Por lo general, en muchos de estos programas subyace no solo una mera ideología de ostentación, sino intenciones de mucho mayor alcance que obedecen a programas políticos profundamente presentes en la mentalidad de su promotor y del círculo de sus allegados y colaboradores.

El reinado de Pedro I y la actividad constructiva que en torno a él tuvo lugar en el reino de Castilla representa un claro ejemplo del soporte que quiso dar a su proyecto político a través de un programa de construcciones de casas, palacios y alcázares reales que a lo largo de su reinado fue levantando y que culminarán en el gran proyecto del alcázar sevillano, síntesis de todos ellos y paradigma de un palacio real para un soberano que aspiraba a colocar a la monarquía por encima de cualquier otro poder o autoridad dentro del reino, en lo que constituye el modelo de los estados modernos que van surgiendo en Europa a partir de mediados del siglo XIII.

En el desarrollo de este programa, Pedro I contó con precedentes importantes por parte de sus predecesores, que desde tiempos de Alfonso X cuidaron de procurarse un entorno arquitectónico adecuado a sus ideas sobre el papel que un monarca debía jugar en la sociedad. Desde la segunda mitad del siglo XIII, encontramos en Castilla palacios reales de gran prestancia frente a los que las residencias de la nobleza apenas rivalizan. El Alcázar de Segovia, el castillo de Burgos, el Alcázar Real de Guadalajara o el palacio alfonsí de Sevilla constituyen precedentes que van a ir definiendo tipológica y funcionalmente las características de los palacios posteriores, y en los que determinadas innovaciones ya apuntan a las soluciones que se adoptan en las construcciones de mediados del siglo XIV.

La mayor parte de estos edificios responde a una disposición de planta muy parecida y que se organiza en torno a un patio rectangular con pórticos en todos sus lados. En cada lateral del patio hay una crujía ocupada por un salón de proporciones alargadas y con una alcoba en cada extremo de planta sensiblemente cuadrada. A los salones se accede por un arco desde la galería del patio y a las alcobas por puertas ubicadas en el centro de los testeros del salón. A ambos lados del arco de entrada al salón suele haber ventanas geminadas para la iluminación de éste. Sobre esta tipología genérica se producen variaciones ya que no todos los salones están acompañados de alcobas pues los espacios correspondientes a éstas pueden estar ocupados por los zaguanes o por otras dependencias o zonas de paso.

Esta organización tiene sus raíces, sin duda, en la arquitectura andalusí en la que desde las construcciones de Madinat al-Zahra, tanto la presencia de patios como de salones con alcobas o alhanías en sus extremos son característicos de cualquier residencia, tanto si se trata de un palacio como de una vivienda humilde. Sin embargo, la disposición de salones en los cuatro lados del patio parece, si no una creación cristiana, sí una tipología mucho más característica de los palacios castellanos que 
de los andalusíes, y lo mismo puede decirse de los patios con pórticos en sus cuatro lados. El precedente más antiguo conocido de esta disposición es indudablemente el llamado Patio de los Pilares de Madinat al-Zahra ${ }^{1}$, en donde aparecen salones en tres de los lados y pórticos en los cuatro. Sin embargo, no conocemos nexo de unión entre este modelo y los palacios castellanos que acabamos de mencionar de finales del siglo XIII, pues el modelo de casa o palacio andalusí posterior al siglo X suele consistir en un patio alargado con pórticos y salones en un lado o en dos lados enfrentados sin que hasta la construcción del Patio de los Leones de la Alhambra encontremos en residencias patios porticados en todo su perímetro. Por tanto, aunque esta tipología de los palacios castellanos deba considerarse de origen andalusí, pensamos que tuvo una evolución propia, adaptada sin duda a necesidades distintas de las que requería una vivienda dentro de la sociedad musulmana, lo mismo que se podría argumentar de la adaptación a otras condiciones climáticas, ya que mientras la presencia de pórticos únicamente delante de los salones respondería a una protección fundamentalmente contra el sol, el pórtico en todo el perímetro del patio podría estar respondiendo a otros condicionantes ambientales como la lluvia o el frío más propios de zonas septentrionales.

El alcázar de Segovia, cuya construcción puede atribuirse a los inicios del siglo XIII o el de Guadalajara ${ }^{2}$, que en su primera fase sería de finales de esa centuria, son ejemplos claros de la adopción de esta tipología. Ambos presentan además una particularidad que debemos resaltar y que es la existencia de terrazas exteriores con acceso desde uno de los salones y que permitían un control visual del territorio circundante. Esta característica, que está presente también en construcciones andalusíes ${ }^{3}$, la vamos a ver adquirir formas diversas en las construcciones de Pedro I, y pueden considerarse modos de manifestación del dominio territorial y por tanto, una manera más de expresión del poder de quien habitaba en esos edificios.

Las construcciones palatinas que de un modo directo o indirecto podemos atribuir a Pedro I de Castilla son cuatro y están ubicados en dos áreas geográficas muy distantes. Dos se encuentran en la vieja Castilla, una en Astudillo y otra en Tordesillas, no demasiado distantes entre sí. Las otras dos están situados en Andalucía, una en Carmona, población muy próxima a Sevilla, en donde se encuentra la que es, sin lugar a duda, la más importante y significativa de todas (Fig. 1).

El orden cronológico de su construcción es el mismo con el que las hemos enunciado, aunque el Alcázar de Carmona resulta de cronología incierta, si bien creemos

1 A. ALMAGRO "The Dwelings of Madinat al-Zahra: A Methodological Approach", G.D. ANDERSON and M. ROSSER-OWEN (eds.), Revisiting Al-Andalus. Perspectives on Material Culture of Islamic Iberia and Beyond, Leiden-Boston, 2007, p. 50-51.

2 A. ALMAGRO Palacios medievales hispanos, Madrid, 2008, pp. 72-76; J. NAVARRO PALAZÓN, "El Alcázar de Guadalajara. Noticias de las excavaciones realizadas durante el año 2005", Castillos de España, 141 (2006), Apéndice. pp. 15-23; y "El Alcázar Real de Guadalajara. Un nuevo capítulo de la arquitectura bajomedieval española", J. MILLÁN MARTÍNEZ y C. RODRÍGUEZ RUZA, (coord.) Arqueología de Castilla la Mancha. I Jornadas. Cuenca 13-17 de diciembre de 2005, Cuenca, 2007, p. 583-613.

3 D.F. RUGGLES, Gardens, Landscape, and Vision in the Palaces of Islamic Spain, Pennsylvania, 2000, pp. 106-9. 

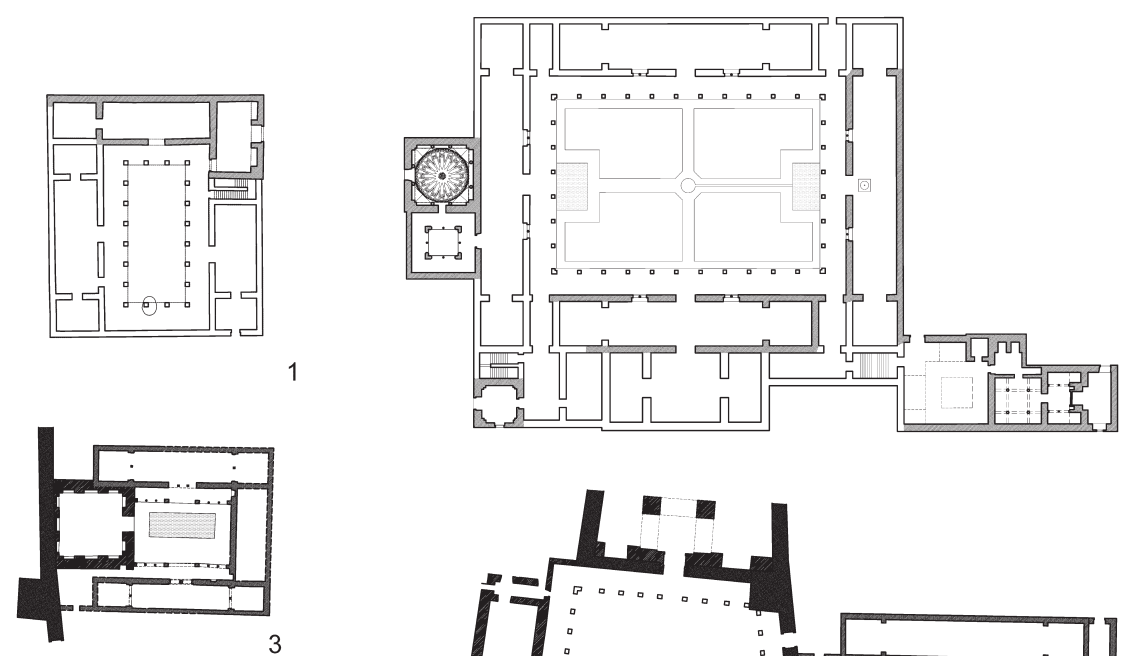

1
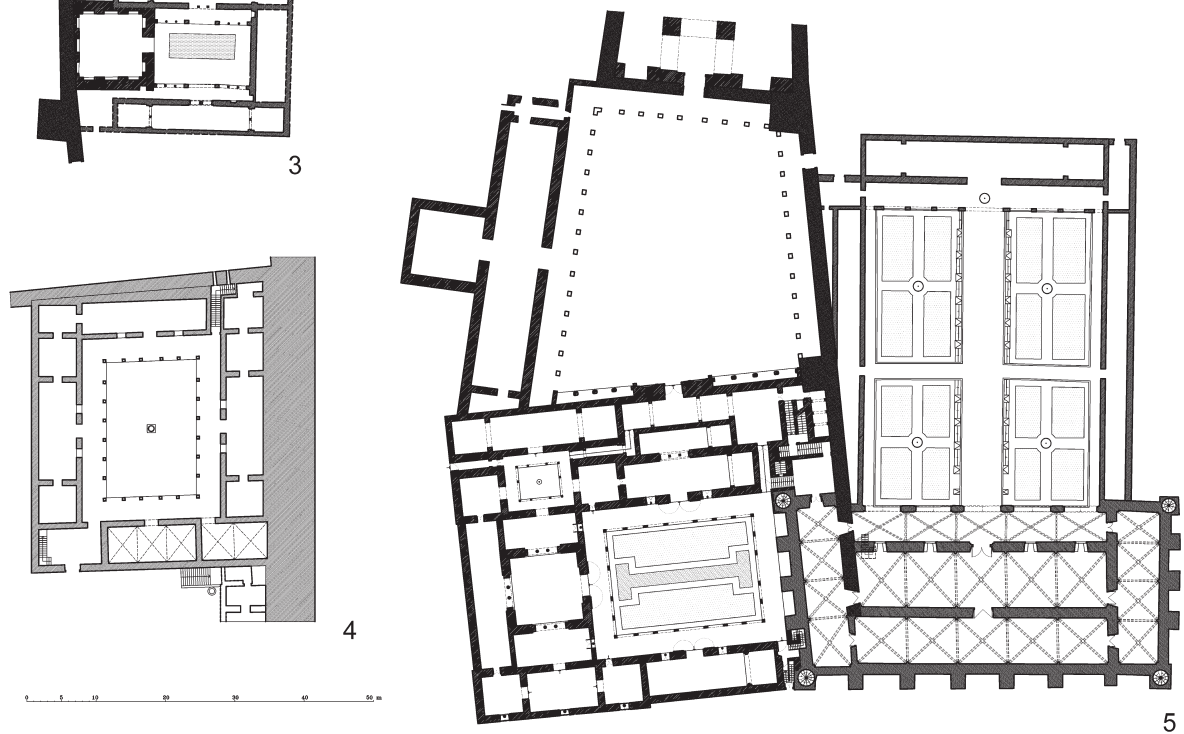

Fig. 1. Plantas de los palacios de Pedro I: 1 Astudillo; 2 Tordesillas; 3 Cuarto del Yeso, Sevilla; 4 Carmona; 5 Alcázar de Sevilla.

que es anterior al Alcázar sevillano. También en su prestancia y complejidad siguen ese mismo orden que es el que mantendremos para realizar su análisis.

Todas ellas presentan rasgos singulares que muestran cómo tanto en su concepción como en su realización final estuvo presente la idea de que sirvieran de forma de expresión de las ideas que albergaba su promotor o inspirador en cuanto a la preeminencia de la monarquía sobre cualquier otro poder o estamento dentro del reino. En nuestro análisis vamos a hacer especial hincapié en la presencia de determinados elementos ligados sin duda a la manifestación visual del poder y que son fundamentalmente los espacios de especial relevancia como salones del trono ligados a formas de alto simbolismo y los lugares de manifestación o expresión externa del poder como puertas y miradores de control del territorio. 


\section{El Palacio de Astudillo}

En la villa palentina de Astudillo doña María de Padilla, a quien en su testamento D. Pedro reconoció como su legítima esposa, fundó un monasterio de monjas Clarisas en $1353^{4}$. Como ocurrió en tantas ocasiones en Castilla, junto al convento se levantó un palacio o residencia que por su tipología y por la estrecha relación que la fundadora tuvo con el monarca, lo hemos considerado dentro de sus realizaciones (Fig. 1, $\mathrm{n}^{\mathrm{o}} 1$ ). Lo que se ha conservado de este palacio es bastante escaso y hay serias dudas sobre lo que llegó a edificarse del mismo. Apenas queda en pié la crujía septentrional que alojaba el salón principal de la residencia (Fig. 2). Junto a éste queda el zaguán y la portada exterior, sin duda lo más sobresaliente y significativo de todo el conjunto. La construcción se realizó en contacto con una primera residencia de aire más austero hoy conocida como Patio Castellano, edificio de tres crujías en torno a un patio adosado al lado occidental del convento. Todo parece indicar que se quiso dar una mayor prestancia a la residencia de quien era de facto la mujer del rey, dotándola de los pertinentes elementos simbólicos y protocolarios, como son una portada de cierta monumentalidad y unos salones de aparato, similares a los que había en los palacios reales.
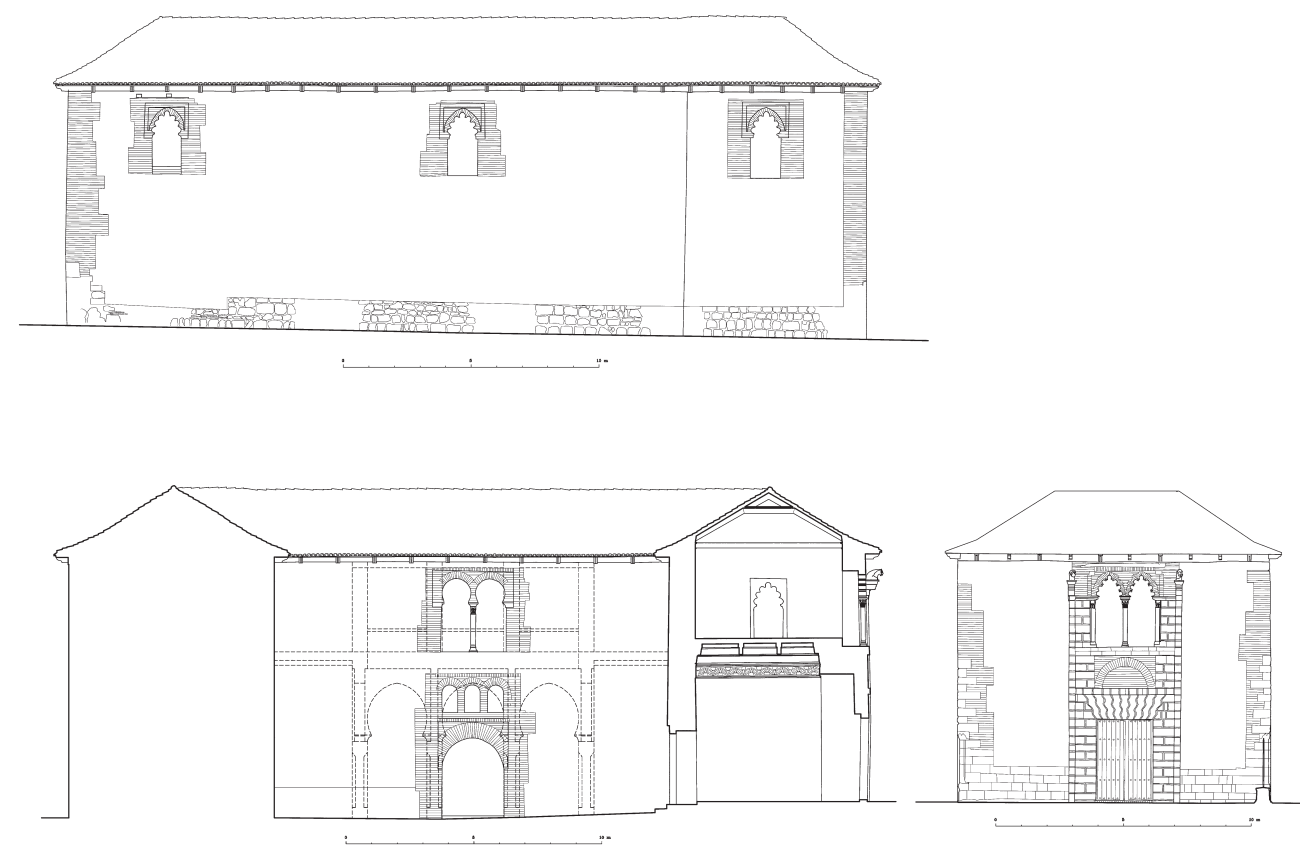

Fig. 2. Alzados del palacio de Astudillo.

4 P.J. LAVADO PARADINAS, "El palacio mudéjar de Astudillo", Actas del II Congreso de Historia de Palencia, Palencia, 1990, pp. 579-599; y "Palacios o conventos: Arquitectura en los monasterios de clarisas de Castilla y León”, Actas del Congreso Internacional: Las clarisas en España y Portugal. Salamanca 20-25 de Septiembre de 1993, Madrid, vol. II, pp. 715-752; y M.T. PÉREZ HIGUERA, Arquitectura mudéjar en Castilla y León, Valladolid 1993, pp. 103-5. 
El edificio estaba organizado en torno a un patio rectangular con orientación nortesur. Aceptando que los restos de muros y cimientos que se han dejado visibles en las restauraciones realizadas corresponden realmente a estructuras que existían o aparecieron en las excavaciones, podemos interpretar que el patio tuvo pórticos en sus cuatro lados obedeciendo al modelo que hemos planteado anteriormente para estos edificios. Por otro lado, la existencia de una planta alta hace casi obligado pensar que existía una galería alta como elemento de comunicación entre las estancias del piso superior. En su frente norte, y orientado por tanto su acceso hacia el sur, se dispuso el salón principal con arco de ingreso desde el patio. Este salón contaría con sólo una alcoba en el lado occidental, arruinada y reconstruida no hace mucho. El espacio correspondiente a la alcoba opuesta forma parte del zaguán del palacio, cuya puerta hacia el exterior se abre en su lado oriental, flanqueada por dos grandes nichos que pudieron tener bancos en sus orígenes. El zaguán se extiende algo más hacia el sur que el salón, permitiendo acceder al patio a través de otra puerta con arco de herradura apuntada situada en el ángulo más meridional del lado opuesto a la portada.

De los espacios que han llegado hasta nosotros, sólo el salón principal y sobre todo el vestíbulo, conservan elementos decorativos. Este último se cubre con un poderoso alfarje policromado y estructurado con tres órdenes de vigas. Sobre ambos espacios existe un piso alto que se cubría con armaduras, hoy desaparecidas. Esta planta alta tiene ventanas hacia el exterior y un arco geminado hacia el patio sobre la puerta del salón principal.

La portada del palacio es seguramente lo más sobresaliente y característico de lo conservado. Al ser la más simple de las tres que han llegado hasta nosotros de este grupo de edificios, puede pensarse que constituye el primer eslabón de una evolución. Presenta dos bandas laterales lisas y otra central de cantería limitada por pilastras simples y dividida en tres cuerpos por dos impostas. El inferior contiene la puerta, adintelada con dovelas engatilladas de juntas sinuosas y con un ligerísimo almohadi1lado. El cuerpo intermedio presenta una zona de fábrica de ladrillo en la que aparece un arco de descarga de luz inferior a la del vano de la puerta. Esta zona pudo estar pensada para ser recubierta con algún tipo de ornamentación hoy perdida o nunca realizada. En el cuerpo alto se abre una ventana de doble arco con columna central.

De todos estos elementos que acabamos de describir merece que resaltemos en primer lugar la presencia de una portada que, aunque simple, muestra un diseño y elaboración muy cuidadosos y que constituye un signo de distinción para el edificio que pone de manifiesto su importancia y la de quien lo habitaba. La presencia del vano geminado en planta alta constituye a la vez un elemento de control, y por tanto signo de dominio sobre el entorno, y un posible lugar desde el que el propietario puede dejarse ver, incluso de cuerpo entero, al tratarse de un hueco que se abre desde el suelo y con altura suficiente como para permitir el paso de una persona. También resulta significativa la apertura de otros huecos hacia el exterior, tanto en el salón alto como en las habitaciones laterales del piso superior, que permiten la visión del entorno que, aunque en este caso resultaba bastante limitada, marca una opción que veremos más acentuada en las otras construcciones. Este palacio de Astudillo constituye la obra más modesta de las realizadas en tiempo de Pedro I, pero resulta muy significativa en 
la organización de la portada así como en la ubicación de ésta en el edificio, constituyendo seguramente un primer tanteo en la búsqueda de las soluciones más elaboradas que aparecerán en los palacios construidos después.

\section{El Palacio de Tordesillas}

Sobre el borde de la meseta que baña el río Duero y en la que se levanta la villa de Tordesillas edificó Pedro I un palacio que constituye, por la regularidad de su diseño, un arquetipo del modelo que venimos analizando ${ }^{5}$. La construcción de este edificio se desarrolló entre 1354 y 1361, año de la muerte de María de Padilla. Al poco tiempo, en 1363, D. Pedro donó el palacio para la fundación de un convento de monjas Clarisas en el que profesó su hija Beatriz. Es muy probable que esta construcción viniera a añadirse, como hemos visto en Astudillo, a un palacio anterior del que parece subsistir algún elemento, mientras otros, de los que existen testimonios, habrían desaparecido. No obstante, el análisis de las construcciones realizadas en torno al actual claustro del convento nos permite identificar una obra que atiende a un proyecto unitario que pensamos sólo puede ser atribuido a Pedro I. Su conversión posterior en convento y las transformaciones consiguientes que se han ido produciendo y acumulando en él han acarreado la desaparición o enmascaramiento de muchas de las estructuras y ornamentaciones originales, lo que dificulta el conocimiento de la forma y disposición del primitivo edificio, habiendo dado lugar a muy variadas interpretaciones.
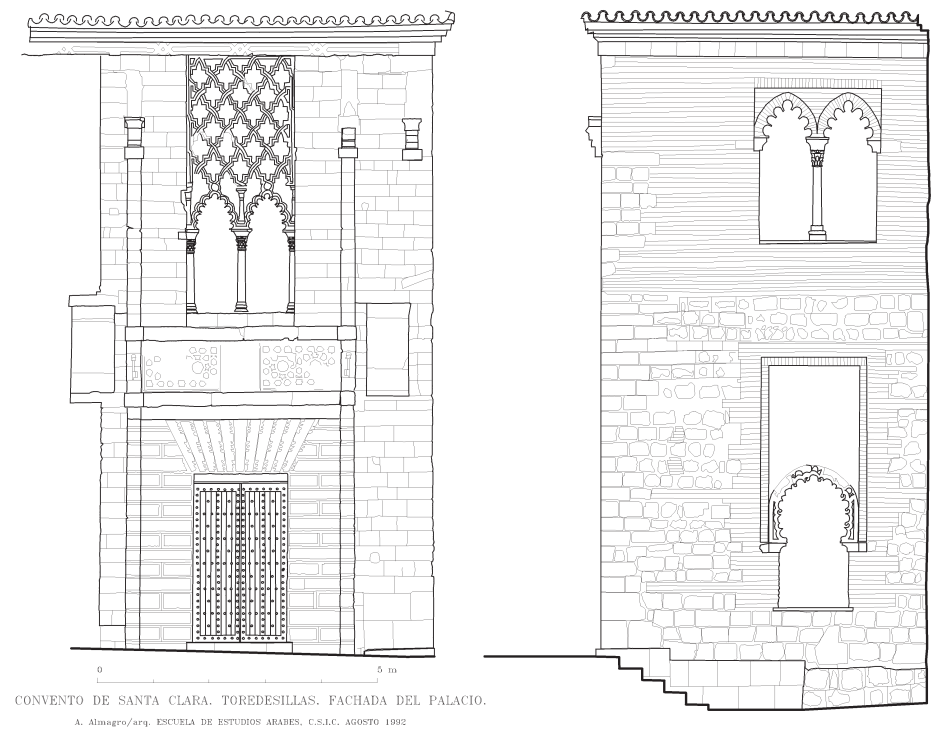

Fig. 3. Alzados del vestíbulo del palacio de Tordesillas.

5 M.L. BUJARRABAL y J.L. SANCHO, "El palacio mudéjar de Tordesillas", Reales Sitios, 106 (1990), p. 29-37; y M.T, PÉREZ HIGUERA, op.cit., 1993, pp. 91-102. 
También aquí el elemento más visible de este palacio es su delicada portada (Fig. 3 ), que resulta mucho más elegante en su diseño y ejecución que la de Astudillo, a lo que contribuye sin duda la fina cantería de piedra blanca con que está realizada. Como aquélla, presenta una composición tripartita, con pilastras que recorren toda la altura de la fachada y enmarcan un hueco de puerta con arco arquitrabado sobre el que se dispone una ventana de doble arco con columna central de parteluz. La puerta tiene dintel de dovelas engatilladas de finísima labra y con alternancia de piezas lisas con otras que muestran decoración de ataurique en su superficie. Sobre el vano de la puerta aparece una cartela con decoración de lazo esculpida que seguramente contó con incrustaciones de piezas cerámicas vidriadas que imprimirían una fuerte nota de color. En la parte alta el vano geminado con arcos de lóbulos se prolonga en trama de sebka. La portada estuvo protegida por un tejaroz que sería prolongación del alero y que estaba soportado por ménsulas de madera cuyos huecos de empotramiento aún pueden verse sobre las pilastras que enmarcan la portada y que rematan en canes de piedra que facilitaban el apoyo de las vigas de madera. A ambos lados de las pilastras se incrustaron dos inscripciones actualmente muy borradas y cuya lectura antigua, hoy dificil de corroborar, ha dado lugar a distintas atribuciones en la construcción del palacio ${ }^{6}$.

Tras la portada existe un zaguán de dimensiones más modestas que el de Astudillo (Fig. 4), pero que presenta una rica decoración con arcos lobulados adosados a sus cuatro lados y yeserías. Se ilumina con una ventana de arco angrelado abierta en su lado sur. Una puerta frontera con la del acceso exterior daría paso a un segundo vestíbulo o corredor a través del cual se llegaría al patio central del palacio. Debió cubrirse originalmente con un alfarje que se eliminó cuando este espacio fue convertido en capilla a la que se dotó de una bóveda de ojivas que prácticamente anuló el espacio de la planta alta. La conversión del zaguán en capilla, que se realizaría a la vez que se construía la iglesia y el coro del convento, debió comportar también el tapiado de ambas puertas y la apertura de otra en el lado norte como acceso desde el antecoro, quedando este elemento totalmente desvinculado del resto de las estructuras del primitivo palacio.

Sobre el zaguán existió una sala de dimensiones modestas, pero posiblemente con funciones representativas y simbólicas importantes. Esta pieza, de planta cuadrada de $5.10 \mathrm{~m}$ de lado, hay que presumirla cubierta por una armadura de artesa de cuatro lados u ochavada, lo que la otorgaría apariencia de qubba. La sala presenta tres vanos, uno de acceso por su lado norte, y otros dos geminados en los lados oeste y sur. El vano de acceso que tenía forma de arco con rica decoración de yesería está hoy tapiado y en su mayor parte destruido, apreciándose sólo restos de la decoración de la jamba izquierda. A él se llegaría seguramente por una escalera que suponemos estuvo adosada al vestíbulo por su lado norte y que probablemente sólo daba acceso a esta habitación, ya que todo parece indicar que este palacio de Tordesillas no tuvo planta alta, al menos en las crujías que rodean el patio.

6 J.C. RUIZ SOUZA, "Santa Clara de Tordesillas. Restos de dos palacios medievales contrapuestos (siglos XIII-XIV)", Actas del V Congreso de Arqueología Medieval Española, Valladolid 1999, Valladolid, 1999, vol. 2, pp. 851-860. 

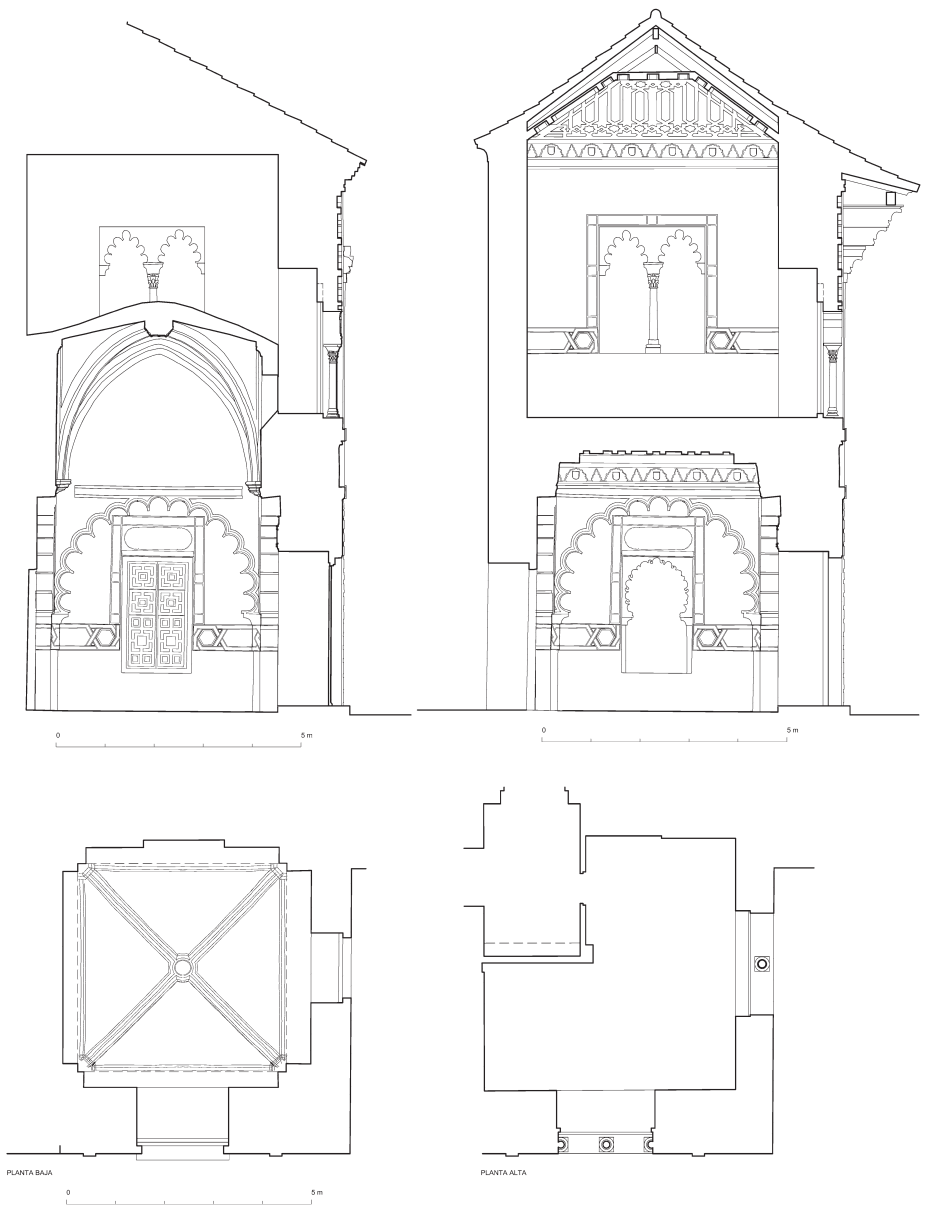

Fig. 4. Secciones actual e hipotética y plantas actuales del vestíbulo del palacio de Tordesillas.

Como en Astudillo, el hueco de la fachada principal está rasgado hasta el suelo permitiendo asomarse por él a una persona de cuerpo entero. El hueco del lado sur tiene antepecho y se abre hacia las dilatadas panorámicas del río y su extenso valle, permitiendo una amplia visión del territorio.

La organización espacial del palacio estaba articulada en torno a un gran patio, (Fig. $1, n^{\circ} 2$ ) cuyas dimensiones coinciden con el actual Claustro del Vergel. Aunque las transformaciones realizadas entre los siglos XVII y XVIII lo dejaron irreconocible, los restos aparecidos durante las obras de restauración llevadas a cabo en 1988 y la documentación del siglo XVIII que describe su estado anterior nos aportan datos que permiten imaginar su primitiva disposición.

La estructura del palacio, tal y como puede deducirse de la interpretación de los restos conservados y de las trazas dejadas por las estructuras desaparecidas, resulta 
totalmente acorde con el modelo que hemos planteado: patio con pórticos en todo su perímetro y salones con alhanías en cada lado del patio. Hay que destacar que aquí en Tordesillas no se dispusieron alcobas (habitaciones cuadradas con puerta de acceso desde el salón) sino alhanías o espacios en los extremos del salón acotados por arcos de luz muy cercana a la anchura de éste.

En el lado oriental del patio se encuentra una de las partes más fácilmente identificables del primitivo palacio, el llamado Salón del Aljibe que conserva su arco de ingreso ricamente decorado, los dos arcos de paso hacia las alhanías ubicadas en los dos extremos del salón y dos ventanas geminadas abiertas hacia el patio, semejantes a las existentes en el Alcázar de Sevilla, y que ya estaban presentes en el Alcázar de Segovia. En el lado sur del patio aparecieron varios huecos que permiten identificar igualmente esta crujía como parte también del palacio, de modo que el llamado Coro Largo correspondería a otro antiguo salón del edificio áulico en el que el presbiterio ocupa exactamente una de las alhanías. La presencia de un gran arco, situado en el mismo eje que el de acceso desde el claustro al Coro Largo, en el muro que separa a éste de la iglesia plantea la segura presencia de algún otro espacio más hacia el sur. La calidad de la decoración con que se ornó este hueco obliga a pensar que daba paso a una estancia de gran importancia, que se demolería para permitir la construcción del actual templo en el siglo XV. En otras ocasiones hemos planteado la hipótesis de que tal espacio pudiera ser una qubba o salón de planta cuadrada ${ }^{7}$ con techo tridimensional basándonos en su presencia en otros palacios anteriores y coetáneos ${ }^{8}$.

La crujía occidental, en donde hoy se encuentra el antiguo refectorio y un pequeño vestíbulo que comunica con el Patio Árabe, debió estar ocupada por un salón simétrico del Salón del Aljibe, del que probablemente aún subsisten sus muros perimetrales que incluso puede que conserven en su interior restos semejantes a los aparecidos en los muros oriental y meridional del claustro. Desde este salón occidental se accedía, a través del Patio Árabe, a la capilla del palacio, hoy conocida como Capilla Dorada, que muy posiblemente formara parte de otra construcción anterior. La crujía norte debió albergar un salón simétrico del correspondiente al Coro Largo que por su orientación al Mediodía bien pudo ser inicialmente la cámara del Rey, a semejanza de lo que ocurre en el Alcázar de Sevilla. Sabemos que este salón estuvo destinado a dormitorio colectivo del convento hasta su demolición en el siglo XVIII para construir celdas para las monjas en una nueva crujía que respetó las dimensiones de la primitiva.

El palacio de Tordesillas presenta una planta más ordenada y simétrica que el de Astudillo, aparte de contar con un mayor tamaño y más rica decoración, mostrando con ello ser sin duda empresa de promoción directa del monarca. Aunque por el momento no deja de ser una hipótesis, creemos que hay razones sobradas para pensar que contó con un salón de trono en forma de qubba que pudo ser cerrado, sin huecos exteriores, como los de Guadalajara y Sevilla, o con aperturas hacia el paisaje como presentan los modelos nazaríes, especialmente el salón de Comares de la Alham-

7 En el verano de 2012 realizamos una prospección con geo-radar en el espacio de la iglesia con el fin de comprobar esta teoría que no ha dado resultados en ningún sentido, ya que no se pudo identificar ninguna estructura, bien porque estuvieran arrasadas o bien porque la naturaleza del subsuelo no lo permite.

8 A. ALMAGRO, op. cit., 2008, pp. 87 y ss. 
bra. A este elemento de alto valor simbólico y de potente imagen hay que añadir la portada con su sala alta, con forma igualmente simbólica y que permitía asimismo un control visual del entorno y una visualización del monarca a través de su hueco geminado. Como analizaremos con más detenimiento en el Alcázar de Sevilla, también aquí podemos suponer que este espacio pudo usarse como sala de recepciones destinada a las audiencias de aquellas personas a las que no se quería permitir entrar en la parte más íntima del palacio.

\section{El Alcázar Real de Carmona}

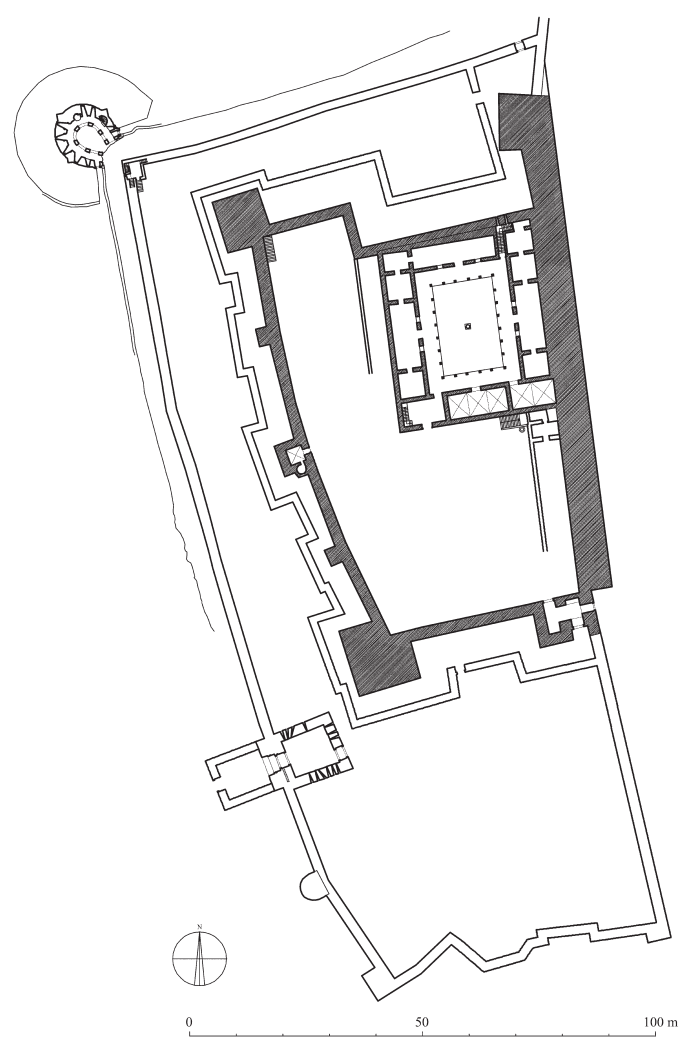

Fig. 5. Planta general del Alcazar Real de Carmona.

El llamado Alcázar de Arriba o Alcázar Real de Carmona fue en sus orígenes la antigua alcazaba árabe convertida en castillo y residencia regia tras la conquista cristiana. Hay constancia de continuas visitas de Pedro I a Carmona durante las cuales debió ocuparse de reforzar y embellecer su alcázar. A la muerte del monarca, Carmona fue la última plaza en rendirse a Enrique II, pues en su alcázar D. Pedro había puesto 
en guarda su tesoro y a sus hijos, señal de que confiaba más en esta fortaleza que en el alcázar sevillano. A él creemos que debe atribuirse la construcción de la barrera más exterior con su doble puerta, foso y barbacana, así como el refuerzo del recinto interior en donde hallamos torres de tapia revestidas de sillería, refuerzo que puede atribuirse igualmente a este momento (Fig. 5). Pero, sobre todo, dentro de él encontramos los restos de un edificio que sigue las pautas de los ya analizados. Desgraciadamente el palacio se arruinó completamente a partir del siglo XVII siendo excavado parcialmente en el siglo XIX cuando se abrieron zanjas a lo largo de los muros. Los resultados los recogió Jorge Bonsor en un plano que ha servido hasta ahora como único documento gráfico que representa la totalidad de la fortaleza 9 . Parece que el edificio principal del palacio estuvo precedido por otro patio que llaman de los Aljibes que quizás pudo hacer también de plaza de armas y del que por ahora apenas disponemos de información, aparte de que sufrió fuerte destrucción al levantarse en él una plaza de toros en 1872. Este patio y el palacio propiamente dicho ocupaban la mayor parte del recinto interior.

La residencia principal del alcázar (Fig. 6) es un edificio rectangular organizado en torno a un patio porticado que según descripciones antiguas disponía de columnas de mármol, material que pudo ser reutilizado de la antigua ciudad romana de Carmo. Descripciones antiguas nos hablan también de decoración de yeserías y alicatados. Las dimensiones de este patio $(26.40$ x 20.00) resultan muy cercanas a las del Alcázar de Sevilla (27.66 x 21.55), lo mismo que la anchura de sus crujías. Según testimonios antiguos contó con una fuente en su centro para cuyo abastecimiento funcionaba una noria que se cita en documento de finales del siglo XVI.

Las cuatro crujías que rodean el patio cuentan con salones con alcobas en sus extremos, salvo en el lado meridional en que se dispuso el zaguán en el ángulo suroeste y una capilla con la advocación de San Juan en el sureste ${ }^{10}$, quedando una sala en el centro. Parece que toda esta crujía estuvo abovedada y con terraza encima ${ }^{11}$. Según la documentación del siglo XVII ${ }^{12}$, la puerta de entrada contó con portada como las de Astudillo o Tordesillas, además de que otro documento nos permite saber que tuvo ventana encima de la puerta con un tejaroz que la protegía ${ }^{13}$, a semejanza del que hemos visto en Tordesillas. Parece que el zaguán tuvo una entreplanta, a la que correspondería la ventana mencionada y al que pensamos pudo subirse por una escalera ubicada dentro del mismo zaguán y a la que correspondería la mampostería que hoy se ve adosada al muro del lado occidental ${ }^{14}$.

9 Publicado en M. FERNÁNDEZ LÓPEZ, Historia de la Ciudad de Carmona, desde los tiempos más remotos hasta el reinado de Carlos $I$. Sevilla 1886. El plano que publicamos ahora está basado en una restitución fotogramétrica aérea y en datos y observaciones medidas in situ tras las últimas excavaciones realizadas.

10 El plano de Bonsor rotula así este espacio.

11 E. MIRA CABALLOS, “Alcázares y alcaides en la Carmona moderna: noticias inéditas", Revista de Historia Militar, 105 (2009]), p. 204.

12 M. FERNÁNDEZ LÓPEZ, op .cit., 1886, p. 283.

13 E. MIRA CABALLOS op. cit., 2009, p. 204.

14 E. MIRA CABALLOS op. cit., 2009, p. 204. 

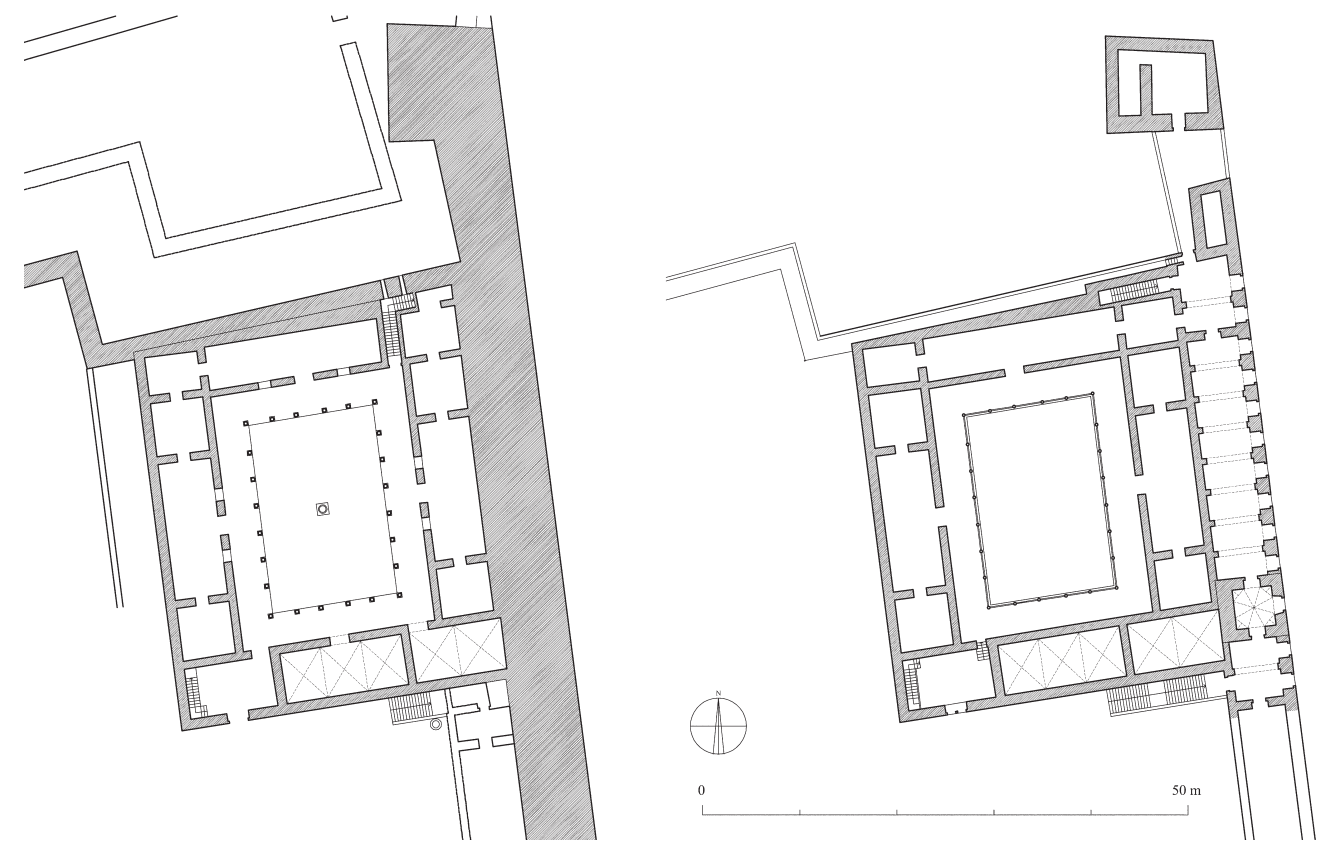

Fig. 6. Plantas baja y alta del palacio. Alcazar Real de Carmona.

En el lado norte, Bonsor dibujó un salón con tres huecos hacia el patio y una alcoba en el lado occidental, solución bastante anómala que recuerda las salas de los Reyes y de los Mocárabes del Patio de los Leones de la Alhambra. En el lado oeste hay un salón con dos alcobas y también con tres huecos hacia el patio ${ }^{15}$, y en el este posiblemente hubo una distribución semejante. Este edificio contó con una planta alta, al menos en parte de él, tal y como puede deducirse de descripciones y documentación antigua ${ }^{16}$ y de la observación del muro de cierre del lado oeste en donde se aprecian restos de la misma.

El acceso a esta planta alta se realizaba mediante una escalera que arranca del ángulo noreste y sube en dirección norte para luego girar hacia el este y desembarcar en una crujía situada sobre la muralla con que se cierra la fortaleza por ese lado. Esta muralla es en todo este lateral de notable espesor, que se logró al reforzarla tanto por el interior como por el exterior con fábrica de cantería con lo que alcanza casi los $7.50 \mathrm{~m}$ de grueso. En esta crujía había un salón o galería que se cita y se describe en

15 Dado el estado de ruina y deterioro que presenta el muro que separa la sala del patio, y de que no se han conservado las jambas de estos huecos, cabe pensar que los laterales pueden corresponder a ventanas luego rasgadas hasta el suelo por usos tardíos del edificio o en el proceso de expolio que sufrió tras iniciarse su ruina. Esta disposición vendría además avalada por los ejemplos de los otros palacios ya mencionados.

16 Un documento de 1592 que valora las obras necesarias en el Alcázar menciona la necesidad de reparar las barandillas que forzosamente deben corresponder a las galerías altas del patio. E. MIRA CABALLOS, op. cit., 2009, p.205. 
documentos de los siglos XVI y XVII como Sala de los Reyes, por disponer de una colección de retratos de monarcas castellanos pintados en sus paramentos, al parecer en tiempo de los Reyes Católicos, cuyas imágenes ocupaban uno de los testeros.

Sabemos que la sala estaba abovedada ${ }^{17}$ y que tenía terraza encima, que funcionaría como adarve de la muralla. Ocho balcones se abrían hacia el este permitiendo una visión completa de la campiña circundante y de una vastísima extensión de territorio. Hemos supuesto la existencia de un vestíbulo basándonos en restos de un muro transversal aún visibles. Casi correspondiendo con el ángulo sureste del palacio, aún se levanta sobre la plataforma de la muralla la mitad de una habitación que debió de ser cuadrada y que estaba construida con cantería. La cubría una bóveda de ocho paños con trompas en los ángulos de tradición almohade que debió estar hecha de ladrillo y de la que sólo ha quedado la masa que la trasdosaba y rellenaba sus riñones ${ }^{18}$. Tenía dos puertas, una hacia el norte y otra hacia el sur y un balcón hacia el este. No sabemos si tuvo hueco hacia el oeste. Por su carácter de espacio cupuliforme y por la calidad de la construcción hemos de considerar que esta habitación pudo ser un aposento del monarca, aunque también podría pensarse que se destinara a guardar el tesoro real. La puerta del norte comunicaba con la Sala de los Reyes, mientras la del sur debía dar paso a un vestíbulo en el que desembarcaba una escalera que subía desde el patio de los Aljibes. Como tendremos ocasión de comentar más en detalle al hablar del Alcázar de Sevilla, esta escalera funcionaría como acceso publico al salón y al aposento real, mientras la que arranca desde el patio interior del palacio sería el acceso privado que además permitiría la circulación interna entre la planta baja y la alta. Más hacia el sur, es posible que existiera otra sala sobre la muralla que podría llegar hasta la torre de la puerta del segundo recinto, pero que no es posible reconstruir al encontrarse esta parte de la plataforma mucho más degradada.

Estos espacios, ubicados sobre la muralla, por su situación y forma, y especialmente por su carácter de lugares que permitían un amplio control del territorio a la vez que podían ser contemplados desde el exterior como los aposentos donde residía el soberano, serían espacios de aparato y a la vez de alto simbolismo, en la línea de los que ya hemos ido encontrando en los edificios antes analizados y de los que vamos a encontrar en el Alcázar de Sevilla. Aunque la portada del palacio haya desaparecido, los datos que nos aporta la visita de los alarifes en 1592 nos indica que hubo un aposento encima del zaguán con una ventana que quedaba justo sobre la puerta y que estaba protegida por un tejaroz. Este aposento alto con acceso desde el mismo zaguán sería similar a los que hemos visto en Astudillo y Tordesillas.

17 El documento de 1592 nos confirma que la Sala de los Reyes estaba abovedada y tenía terraza. E. MIRA CABALLOS, op. cit., 2009, p. 205.

18 Aunque no ha quedado ni un solo ladrillo in situ, podemos deducir que su sistema constructivo era similar al de la torre que se levanta en el centro del lado occidental del recinto interior del alcázar, en donde aún queda alguno visible. 


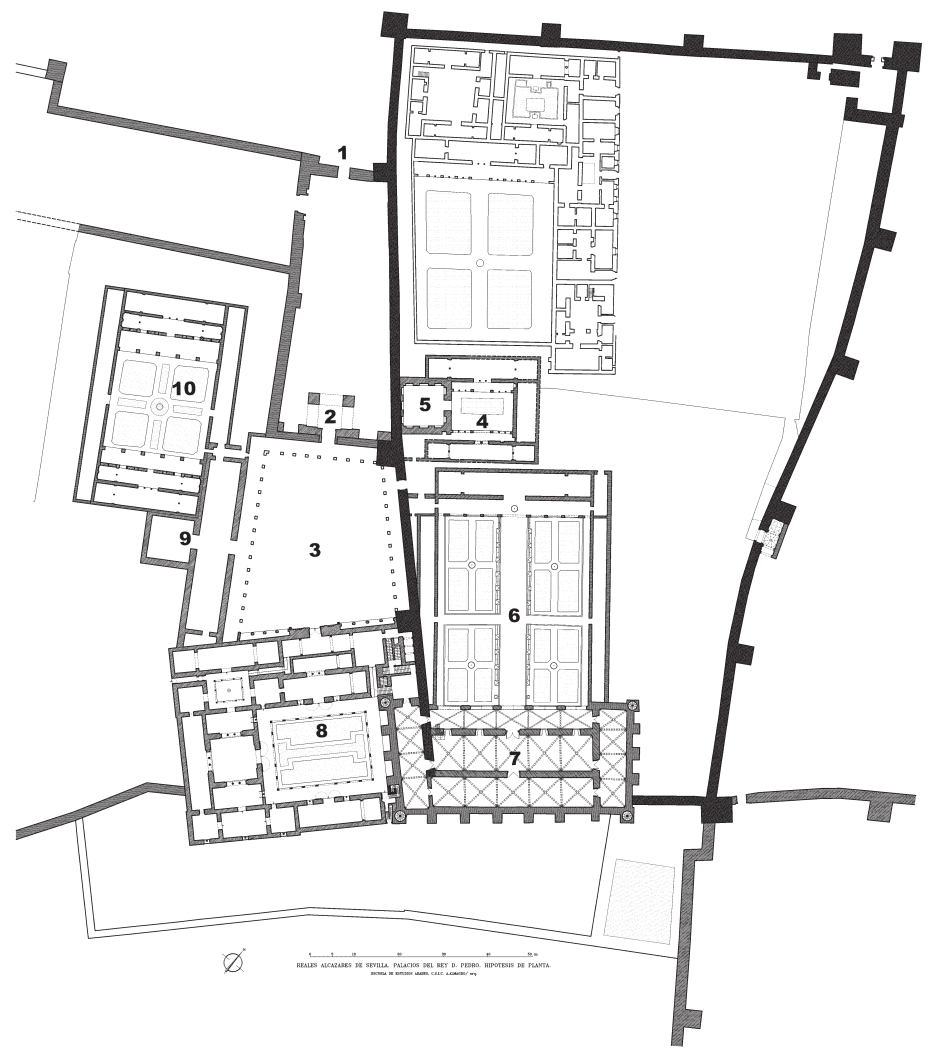

Fig. 7. Planta del Alcázar de Sevilla en el siglo XIV.

\section{El Alcázar de Sevilla}

El proyecto de Pedro I en el Alcázar de Sevilla es sin duda el más ambicioso, completo y de mayor calado de cuantos estamos analizando. En un terreno llano, en el que a diferencia de Tordesillas o Carmona, la visión lejana del palacio en lugar prominente no podía usarse como recurso para marcar la importancia de la obra y el poderío de su promotor, se emplearon otra serie de recursos, muchos de ellos de auténtica naturaleza escenográfica. En Sevilla, Pedro I concibió un nuevo programa arquitectónico en un espacio situado al oeste del recinto más antiguo del Alcázar, en lo que se conoció a partir de entonces como Alcázar Nuevo (Fig. 7), destinado a dotar al poder real de un escenario acorde a su concepto de la monarquía entendida con absoluta preeminencia sobre cualquier otro poder o estamento, y en especial sobre la nobleza.

La nueva residencia real, simbolizada en una monumental portada, mayor y mucho más rica que todas las que hemos visto, ocupaba el final de un trayecto lineal controlado mediante filtros constituidos por recintos sucesivos y sus correspondientes 
puertas. A medio camino entre la puerta más exterior y la nueva fachada del palacio se interponía una muralla que se forró exteriormente con una composición de fachada ornamentada, preludio de la que se alzaba detrás (Fig. 7, $\mathrm{n}^{\circ}$ 2). Como en aquélla, su cuerpo central se realizó en cantería mientras que a los lados se desarrollaba con fábrica de ladrillo. Todo el arco, de forma ojival, está ornado con signos heráldicos de leones, castillos y bandas. Su tímpano, que sería ciego ${ }^{19}$, debió ostentar estos mismos signos a mayor tamaño. Es posible que en su centro y cobijando la puerta, hubiera una construcción a modo de pórtico o arco de triunfo ${ }^{20}$, que pudo haberse concebido como solio de la justicia del rey para sustituir al que funcionó junto a la actual puerta del Patio de Banderas ${ }^{21}$. Este emplazamiento, en una puerta del palacio pero siendo puerta interior, daba mayores garantías de seguridad al monarca.

A través de esta puerta, se accede al patio de la Montería, que puede considerarse centro neurálgico del nuevo proyecto (Fig. $7, \mathrm{n}^{\circ} 3$ ). El aspecto actual del patio difiere sin duda del inicialmente diseñado pues sólo el lado sur ha conservado un aspecto cercano al primitivo, salvo las zonas altas de los laterales que están recrecidas en época de los Reyes Católicos y hay que imaginar que el cuerpo central, que contiene la sala de audiencias privadas del rey, resaltaría mucho más prominentemente en su origen al quedar exento en la parte alta. Para imaginar la organización del resto del perímetro del patio debemos fijarnos en las dos arquerías de ladrillo que acompañan a la portada y que carecen de sentido y utilidad salvo que las veamos como parte de una composición global que se extendería a todos los lados del patio pero que seguramente nunca llegó a terminarse.

En el lado oeste el pórtico estaría previsto en la misma línea del actual. Al analizar la planta de esta zona se aprecia la existencia de una gran sala alargada paralela al pórtico y otra sala cuadrada que se adosa en su centro (Fig. 7, n ${ }^{\circ}$ 9). Esta distribución aparece en todos los planos que conocemos desde comienzos del siglo XVII hasta hoy. Su disposición es semejante a la que encontramos en otros palacios castellanos de fecha anterior como el Alcázar de Guadalajara ${ }^{22}$ y muy posiblemente el palacio de Tordesillas, así como en el que por esos mismos años se levantó en la Alhambra, formado por el Salón de Comares y la Sala de la $\mathrm{Barca}^{23}$. Documentación de la primera mitad del siglo XVI menciona esta zona como Cuarto de la Montería, que quedó inacabado en tiempos de D. Pedro y que se concluyó con el aspecto actual en la segunda mitad de ese siglo. Además, la sala cuadrada, que correspondería a una qubba,

19 Así se deduce de la posición de los huecos de empotramiento de la viga que contenía las gorroneras de las hojas de la puerta y por semejanza con el arco de ingreso del convento de Santa Isabel de los Reyes de Toledo, de diseño sin duda inspirado en éste del alcázar sevillano.

20 A. JIMÉNEZ MARTÍN, "La explanada de Ibn Jaldun. Espacios civiles y religiosos de la Sevilla almohade", M. GONZÁLEZ JIMÉNEZ, Sevilla 1248, Congreso internacional Conmemorativo del 750 Aniversario de la Conquista de Sevilla por Fernando III, Rey de Castilla y León, Sevilla, 1998, p.52; A. ALMAGRO "La recuperación del jardín medieval del patio de las doncellas", Apuntes del Alcázar de Sevilla, 6 (2005), p. 62; M.A. TABALES RODRÍGUEZ, "Investigaciones arqueológicas en el Patio del León", Apuntes del Alcázar de Sevilla, 7 (2006), pp. 24-28.

21 R. CARO, Antigüedades y Principado de la Ilustrisima Ciudad de Sevilla y Chorographia de su Convento Iuridico, o Antigua Chancilleria, Sevilla, 1634.

22 Vid. supra nota 2.

23 A. ORIHUELA UZAL, Casas y palacios nazaries, Siglos XIII-XV, Barcelona 1996, pp. 86-91. 
tiene una cornisa semejante a las que tenían los cuerpos altos del palacio de D. Pedro, de las que aún se conservan algunos fragmentos en los espacios bajo cubierta. Teniendo en cuenta, como veremos, el carácter de residencia doméstica que parece tenía lo que hoy conocemos como Palacio del Rey D. Pedro, podemos plantear la hipótesis de que lo que se proyectó aquí fue ni más ni menos que un gran salón del trono para las audiencias públicas, con una clara separación entre el espacio destinado al rey y el que ocuparían la mayoría de los cortesanos ${ }^{24}$.

Dentro de este esquema, la construcción del Cuarto de la Montería hay que entenderla de nuevo en base a funciones simbólicas. Los salones del Cuarto del Caracol o palacio de Alfonso X (Fig. 7, $\mathrm{n}^{\circ}$ 7) carecen de todo carácter emblemático y representativo al no tener un centro claro de focalización, como de hecho les ocurre a todas las salas principales de proporción alargada de las casas y palacios andalusíes y castellanos. De ahí la adopción de la qubba, espacio centralizado y focalizado, que además por su cubrición que recuerda la de una semiesfera, tiene fuertes connotaciones cósmicas.

De hecho, el Alcázar de Sevilla está lleno de estas construcciones. Hay una de época almohade en una alcoba de un palacio existente en el lado occidental del Patio de Banderas ${ }^{25}$. Otra hay en el Cuarto del Yeso (Fig. 7, $\mathrm{n}^{\mathrm{o}}$ 5) y D. Pedro construyó tres con su proyecto, una dentro de su palacio privado, la sala de la Media Naranja hoy llamada salón de Embajadores, que apenas era visible desde el exterior. También tenía otra qubba en el piso alto, ésta sí visible desde el patio (Fig. 8).

Pero estas dos qubbas eran salones que quedaban dentro del ámbito privado de su palacio. Por esto se entiende que proyectara otra qubba, de dimensiones prácticamente iguales a la del salón de la Media Naranja, y con disposición axial dentro del patio y acceso directo desde el mismo. Estaba precedida de un gran salón a modo de antesala, perfectamente separado de la sala del trono siguiendo viejos modelos orientales, como el del alcázar omeya de $\mathrm{Amman}^{26}$ en que la sala del trono queda incluso fuertemente independizada de la antesala como forma de expresar la separación debida entre el soberano y sus súbditos. Su función no podía ser otra que la de proporcionar una nueva forma de visualización del poder real, con dimensiones y emplazamiento adecuados para ser percibidos por una muchedumbre congregada en el patio, pero convenientemente controlada tras haber pasado por las puertas del León y de la Montería. El tejado de la qubba sería perfectamente visible desde el patio y aparecería con toda su fuerza simbólica conformando un nuevo polo de atracción en la composición del conjunto. La disposición de esta gran sala de recepciones públicas

\footnotetext{
24 A este respecto es interesante resaltar la diferencia de proporciones que existe entre la sala y la qubba en los palacios cristianos y en los musulmanes. Los salones alargados son mucho mayores en los palacios castellanos (Guadalajara, Tordesillas o éste de Sevilla) mientras la qubba de Comares es mucho mayor que las cristianas. Esto podría interpretarse como una respuesta a una corte y séquito real más numeroso en Castilla que en el reino nazarí.

25 A. ALMAGRO, "Sistemas constructivos almohades: estudio de dos bóvedas de arcos entrecruzados", S. HUERTA, et alii (eds.), Actas del Séptimo Congreso Nacional de Historia de la Construcción, Santiago 26-29 octubre 2011, Madrid, 2011, pp. 48-51.

26 A. Almagro, P. JIMÉNEZ y J. NAVARRO, El Palacio Omeya de Amman, III, Investigación arqueológica y restauración 1989-1997, Granada, 2000, p. 162, Fig. 53.
} 
con acceso directo desde el patio resulta muy parecida a lo que algún tiempo después harán los sultanes otomanos en el Topkapi Saray de Estambul ${ }^{27}$ con las salas del Diwan dispuestas en el segundo gran patio interior, adosadas pero independientes del Harén donde se encontraba la residencia privada del sultán o con el Arz Odasi, sala del trono y de audiencias del propio sultán construida en el tercer patio. Todo esto nos vuelve a recordar la organización de la Alhambra, con el Mexuar junto a la entrada como zona pública del palacio, la gran fachada de Comares y el palacio del mismo nombre como residencia privada del soberano.

\section{La residencia privada}

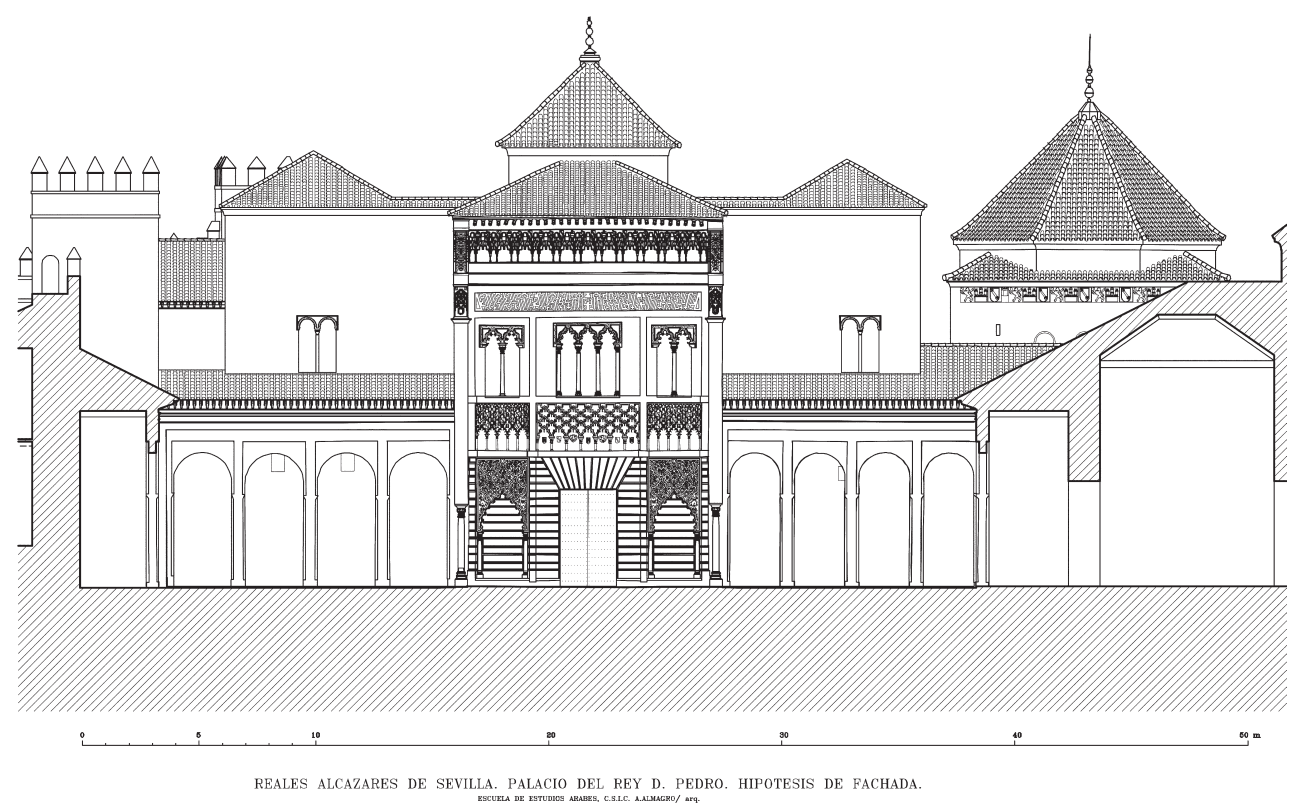

Fig. 8. Alzado del palacio de Pedro I del Alcázar de Sevilla.

El hoy llamado Palacio del rey D. Pedro, levantado en el lado sur del patio de la Montería representa uno de los más claros ejemplos del uso de la arquitectura como simbolización del poder de un soberano (Fig. $7, \mathrm{n}^{\circ} 8$ ). Sin duda el elemento más visible de todo el conjunto es la fachada principal cuyos cuerpos laterales presentan en planta baja las antiguas arquerías con que se concibió el patio, que fueron tapiadas seguramente a finales del siglo XV y reabiertas en 1937 (Figs. 8, 9). La portada que ocupa la zona central de la fachada y está construida con sillería, presenta una compo-

27 J.D. HOAG, Arquitectura Islámica, Madrid, 1976, pp. 340-342 


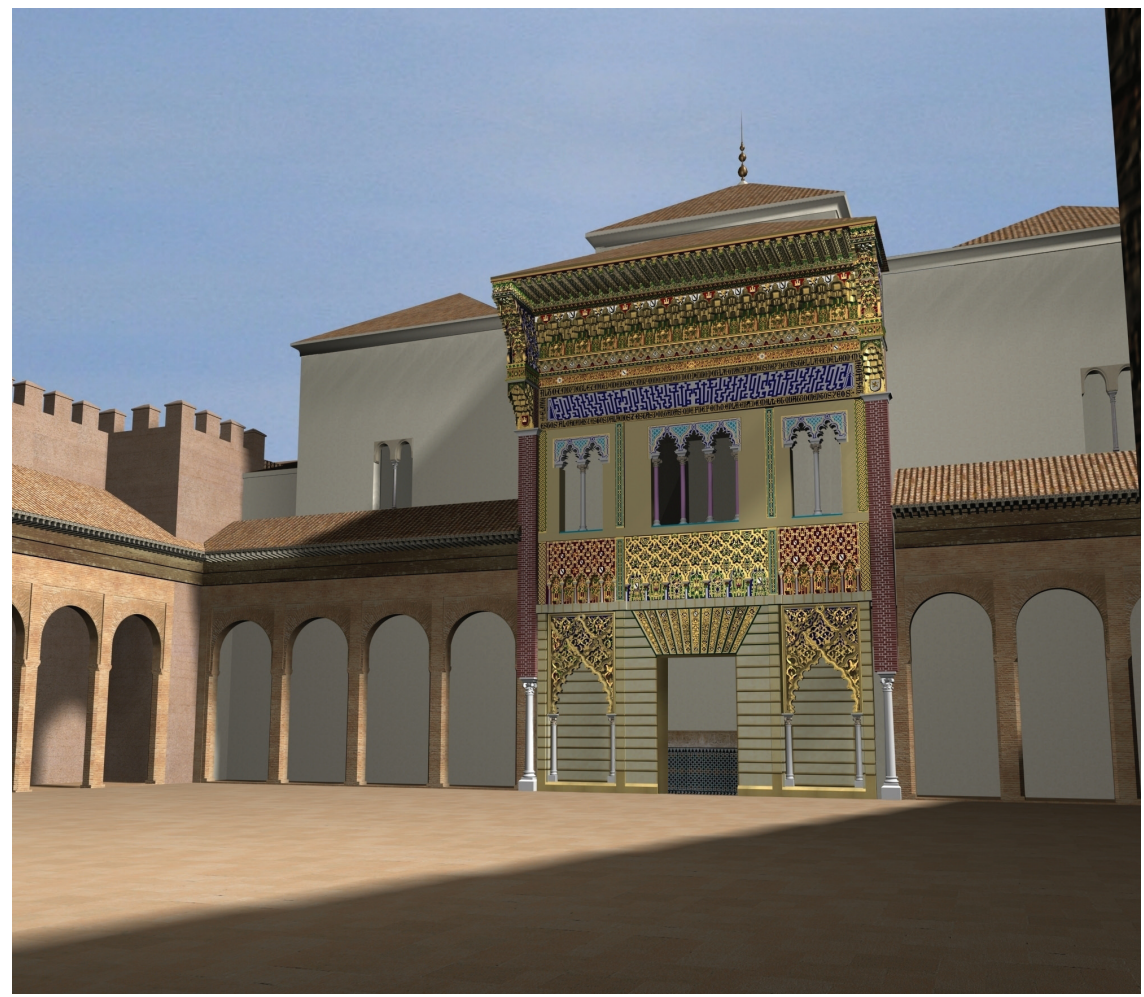

Fig. 9. Reconstrucción virtual de la fachada del palacio de Pedro I del Alcázar de Sevilla. (Hipótesis de A. Almagro, imagen de M. González).

sición tripartita con tres calles verticales y otras tantas bandas horizontales, separadas por impostas y pilastras lisas. La calle central contiene en su parte baja la puerta, de forma rectangular con dintel adovelado decorado con fino ataurique mientras en cada una de las dos calles laterales hay un arco lobulado apeado en columnas de mármol y del que arrancan pañosos de sebka. En la banda superior hay tres huecos con arcos lobulados correspondiendo con cada calle, tripartito en la central y geminados en las laterales.

Coronando la portada se desarrolla un gran alero de madera tallada que la remata y protege y que ha conservado su rica policromía ${ }^{28}$, que nos permite imaginar el aspecto imponente que presentaría toda la portada iluminada mediante vivos colores y dorados que acentuarían notablemente la atracción visual de este elemento convertido

28 Bien es cierto que gracias a los muchos repintes que sólo en algún caso han alterado los colores originales. A. ALMAGRO (coord.) et alli, "La portada del palacio de Pedro I. Investigación y restauración", Apuntes del Alcázar de Sevilla, 10 (2009), pp.6-47; O. LÓPEZ CRUZ, A. GARCÍA BUENO y V. MEDINA FLOREZ, "Evolución del color en el alero de la fachada del rey Pedro I, Real Alcázar de Sevilla. Aportaciones del estudio de materiales a la identificación de las intervenciones de restauración a lo largo de su historia", Arqueología de la Arquitectura, 8 (2011), pp. 163-178. 


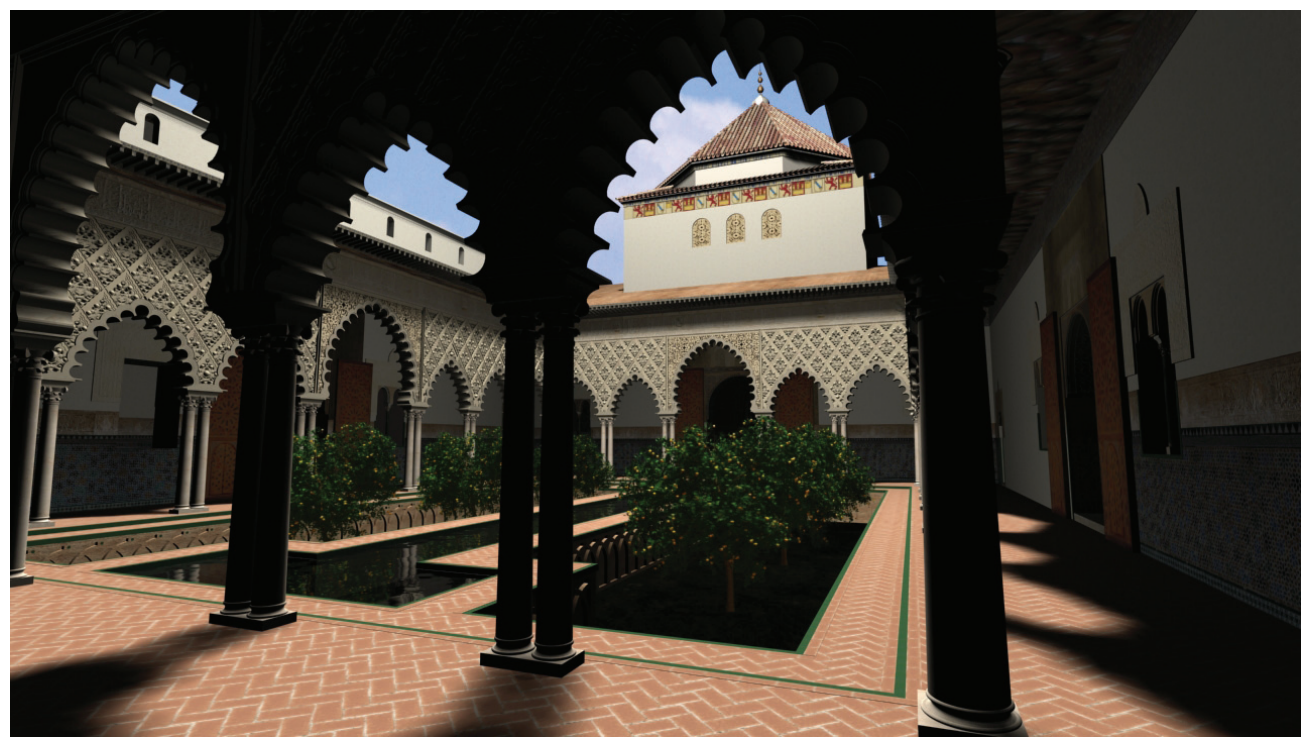

Fig. 10. Reconstrucción virtual del patio del palacio de Pedro I del Alcázar de Sevilla. (Hipótesis de A. Almagro, imagen de M. González).

en el auténtico foco de todo el conjunto. En la reciente restauración han aparecido indicios de que la fachada de piedra estuvo policromada y dorada al igual que el alero.

No cabe duda de que esta gran portada que preside la fachada se situó cuidadosamente en el nuevo eje formado por las distintas puertas que permitían atravesar las murallas de los sucesivos recintos. Con ello se rompe el principio que preside la organización de los palacios musulmanes donde se evita de manera radical que desde el exterior pueda verse el interior de cualquier vivienda y más aún de un palacio. En la organización planificada por D. Pedro se busca lo contrario, al menos hasta la puerta de la morada del rey. La gran portada del palacio queda así visible desde el exterior, planteada como auténtico solio real, símbolo del monarca, que además tiene su sala de audiencias justo encima de la puerta, con amplios ventanales dando a la plaza interior.

La organización interna del palacio sigue las pautas de los edificios antes analizados aunque con significativas variantes. El patio principal, el de las Doncellas (Fig. 10), tiene pórticos perimetrales y contaba con un jardín rehundido dispuesto en dos espacios simétricos que quedaban separados por una alberca longitudinal rematada en sus extremos con forma de T. La existencia de este jardín es uno de los argumentos que permiten suponer que este palacio se concibió como residencia privada del monarca, al modo de los palacios islámicos, por lo que el patio no se pensó para el deambular de los cortesanos sino para deleite de quien allí vivía.

Sólo hay salones con una única alhanía en dos de sus lados. El situado al norte tiene otro adosado de menor anchura, también con una alhanía, y se considera como la cámara y alcoba real, mientras la sala meridional se interpreta como capilla a causa 
de las inscripciones de carácter eucarístico que ornan su puerta. La presencia de la sala de la Media Naranja o salón de Embajadores en el lado occidental constituye una alteración del esquema general, aunque tiene un directo precedente en el Cuarto del Yeso tras la inclusión de la qubba de la Sala de la Justicia. Hasta aquí el esquema resulta aún bastante similar al de los demás palacios, pero éste se complica notablemente en la zona occidental con soluciones que, aun utilizando elementos y disposiciones de clara ascendencia andalusí, han dado como fruto final una organización con una complejidad nunca vista en esa arquitectura.

En torno a la gran qubba y en diáfana comunicación con ella se disponen tres salas, dos a modo de alhanías mientras la tercera, situada a occidente, conforma una composición que podría tener precedente en algún palacio toledano ${ }^{29}$ y que a su vez tendrá un reflejo posterior en la Sala de las Dos Hermanas del Cuarto de los Leones de la Alhambra. La naturaleza de este espacio que fluye por las salas laterales no parece estar concebida como un salón del trono, sino más bien como un lugar de reuniones $\mathrm{y}$ recreo directamente vinculado con el jardín del patio.

A este conjunto de la qubba y sus espacios satélites se adosan otros dos. Uno más sencillo hacia el sur, compuesto por una sala con dos alcobas y otro al norte con estancias en torno a un patio, hoy llamado de las Muñecas, que constituye el núcleo secundario de este palacio y que tiene un acceso directo desde el primer vestíbulo, a través de un estrecho corredor en recodo.

\section{La planta alta}

Una de las características más originales de este palacio es la presencia de un piso alto de muy refinada concepción que no se extendía sobre la totalidad de la planta inferior, sino sólo sobre algunas partes y que constituía el llamado Cuarto Real Alto (Fig. 11). Para el acceso a esta planta alta tuvieron que construirse varias escaleras, cuya ubicación y diseño muestran sin duda un gran talento pues contrastan con las soluciones que se pueden ver en la arquitectura coetánea. En este Alcázar encontramos tres escaleras, dos para acceder a los aposentos principales del piso alto situados al norte, y otra para subir a los apartamentos del lado sur. Las dos escaleras de la zona principal tienen la particularidad de hallarse en proximidad una de otra, existiendo un punto en que se comunican, pero teniendo cada una arranque y final en distintos lugares.

Una de las escaleras, la que vamos a denominar escalera "pública", arranca desde un pequeño vestíbulo al que se accedía desde el segundo zaguán de entrada al palacio (Fig. 1, $\mathrm{n}^{\mathrm{0}} 5$ ). Sube en dirección perpendicular a la fachada hasta un punto en que gira $180^{\circ}$ para continuar en dirección contraria. El lugar en que desembarca hace pensar que desde ella se accedía a la sala del extremo oriental de la crujía de fachada.

La segunda escalera, que vamos a denominar "privada", arranca de un ángulo de lo que en sus tiempos fue un patio que constituía el nexo de unión entre el nuevo palacio

29 J. PASSINI, Casas y casas principales urbanas. El espacio doméstico de Toledo a fines de la Edad Media, Toledo, 2004, pp. 87-89. 


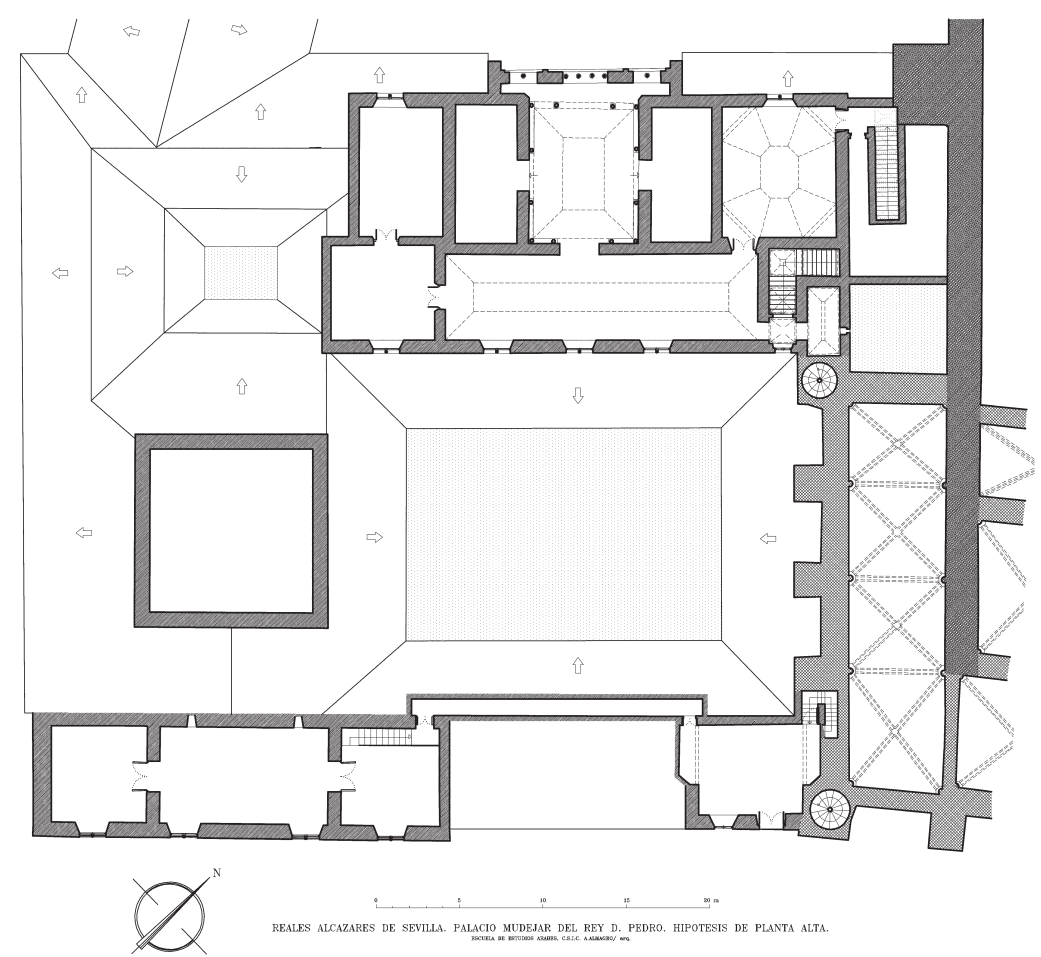

Fig. 11. Planta alta del palacio de Pedro I en el Alcázar de Sevilla.

y los salones del palacio de Alfonso X. En este caso, la escalera se desarrolla en dos tiros perpendiculares entre sí y desembarca en un pequeño vestíbulo por el que se accede a un salón que ocupa la crujía más inmediata al patio interior.

Los aposentos principales de la planta alta, situados encima de los vestíbulos y de la cámara del rey, están constituidos por un salón alargado dispuesto en paralelo al patio y una sala casi cuadrada, a modo de qubba. Es decir, la misma estructura que presenta el Cuarto de la Montería, con una sala para los cortesanos y un salón del trono o sala de audiencia con posibilidad de mantenerse independizados, marcando de este modo una separación entre el monarca y sus súbditos a la manera de muchos protocolos de tradición oriental que llegaban a ocultar al soberano de la vista de los presentes mediante un cortinaje.

La particularidad de esta qubba es que tiene integrada una galería o balconada abierta hacia el Patio de la Montería ocupando la parte superior de la fachada en la que se abren tres grandes ventanales desde los que podía aparecer ante sus súbditos congregados delante del palacio (Fig. 12). Su volumen externo aparece además por detrás de la portada, realzando la importancia y simbolismo de este espacio. Completan este conjunto alto de habitaciones una sala cuadrada en el extremo del salón 
a modo de alcoba, y otras dos salas en ambos extremos de la crujía de fachada, de las que la del lado oriental consideramos que funcionaría como vestíbulo del Cuarto Real Alto.

La presencia de este salón de recepciones con vistas al exterior, que pudo estar pensado para que el monarca apareciera ante sus súbditos congregados en el patio, puede tener relación con la existencia de salas de recepción ubicadas sobre las puertas de los palacios que encontramos en algunas residencias omeyas del desierto de Siria (Jirbat al-Mafyar ${ }^{30}$, Qastal ${ }^{31}$, Qasr al-Hayr al Garbi ${ }^{32}$...) y en Madinat al-Zahra, en donde parece que hubo un pabellón sobre la Bab al-Suda o puerta principal del alcá$\operatorname{zar}^{33}$. Este tipo de sala también está presente en algunos palacios de época mameluca de El Cairo ${ }^{34}$, aunque tampoco podemos olvidar que en el occidente cristiano era habitual ubicar la residencia de los monarcas y sus salas de recepción en las plantas altas $^{35}$. Ya hemos visto la existencia de salas altas sobre los zaguanes de los otros palacios construidos por Pedro I, algunos de los cuales pudieron tener un uso semejante, aunque bien es cierto que nunca alcanzan el protagonismo y la percepción que en este caso tienen. Sin embargo, hasta ahora no conocemos ningún ejemplo semejante en la arquitectura islámica andalusí. En época más tardía, resulta interesante constatar la existencia de salas de recepción del dueño de la casa en viviendas y residencias marroquíes, de origen morisco, que tiene la particularidad de estar situadas en el piso alto y disponer de una escalera para su acceso que arranca desde el zaguán, independiente de la escalera interior de la casa por la que el dueño puede también llegar a esa sala ${ }^{36}$.

En la crujía meridional del palacio sevillano hubo otras dependencias en planta alta. En el lado oriental hay una sala con un gran ventanal hacia el sur que bien pudo ser un mirador sobre las huertas y jardines. En el lado occidental había una algorfa, con una sala y dos alcobas, que pudieron ser dependencias privadas de uso invernal. El acceso a estas dependencias altas del lado sur se hacía por una escalera situada en el ángulo oriental del patio que desembocaba en la alhanía oriental que tiene la salamirador. En la alhanía opuesta, que debía ser simétrica aunque hoy esté cercenada por la construcción del mirador de los Reyes Católicos, había otra puerta aún visible en el lado de la galería, que daría paso a un corredor parecido al existente en el Patio de los Leones para acceder al llamado Patio del Harén, a través del cual se llegaría a la algorfa del lado suroeste en donde hay huella de otra puerta.

30 K.A.C. CRESWELL, Early Muslim Architecture, Oxford, 1969, vol I, part II, p. 558, Fig. 600.

31 P. CARLIER, y F. MORIN "Recherches Archéologiques au Château de Qastal (Jordanie)", Annual of the Department of Antiquities of Jordan, XXVIII (1984), pp. 348-349, 372-374.

32 D. SCHLUMBERGER, Qasr el-Heir el-Garbi, Paris, 1986, pl. 42-43.

33 Véase mi hipótesis de reconstrucción de este elemento en A. ALMAGRO, Planimetría de Madinat alZahra, Granada, 2012, pl. 23.

34 J.C. GARCIN, Palais et maisons du Caire, Paris 1982.

35 A. ALMAGRO, op. cit., 2008, p. 65, 109.

36 Es el caso de Dar Karrakchu y Dar Lamrini en la medina de Rabat o Dar Auad en la de Salé (J. HASSAR BENSLIMANE, Salé, Étude architecturale de trois maisons traditionnelles. Études et Travaux d'Archéologie Marocaine VII, Rabat, 1979. p. 80-81). 


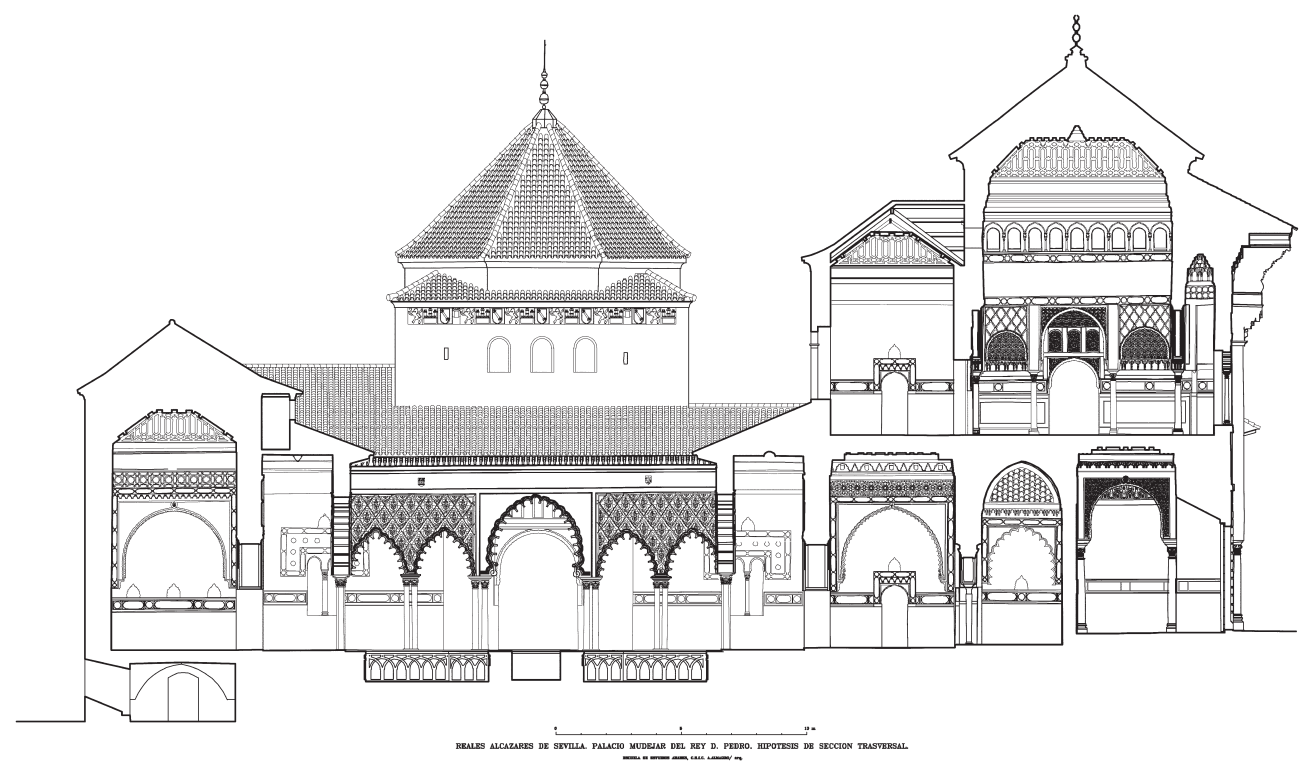

Fig. 12. Sección del palacio de Pedro I en el Alcázar de Sevilla.

\section{Conclusiones}

Los diferentes palacios levantados por Pedro I en distintas zonas de su reino, estaban destinados sin duda a ser un fiel exponente de su pensamiento político. La magnitud y originalidad de su programa constructivo, pese a que en muchos casos no pudo verse concluido, configuró una serie de edificios de gran originalidad y en los que se aprecian algunos rasgos y elementos comunes que guardan sin duda relación directa con la manifestación de sus ideas políticas: la preeminencia del poder real y su expresión a través de símbolos e imágenes de fácil interpretación.

Todos los edificios palatinos obedecen a un mismo modelo, organizados en torno a un patio rectangular porticado en sus cuatro lados y con salas alargadas en cada uno de ellos con alcobas o alhanías en sus extremos. Este modelo hasta ahora descrito sigue pautas lejanas de la arquitectura andalusí y precedentes inmediatos de otros palacios reales levantado por sus predecesores. Sin embargo, a estos caracteres básicos podemos añadir otros específicos que tendrán además una continuidad en construcciones palatinas posteriores.

En todos los palacios hemos visto la presencia de una portada, que con decoración más o menso rica, indica que se trata de morada regia o principal proporcionando una imagen externa que rompe la austeridad de los alzados que, a semejanza de los de las residencias islámicas, están prácticamente desprovistos de ornamento. Las portadas ocupan siempre un lugar extremo en la fachada, condicionado por la forma de ingreso al patio que se hace por uno de los ángulos. Sólo en Sevilla la escenografía 
arquitectónica dispuesta para todo el conjunto palatino condicionó una situación centrada que obligó al desarrollo de un sistema de zaguanes mucho más complejo que el de los otros edificios. Sobre los zaguanes hay siempre un espacio o sala que debió jugar papel importante en el protocolo, bien como sala de audiencia o como lugar en donde el monarca podía ser visto desde el exterior del palacio. Estas salas altas tienen siempre acceso desde los zaguanes del edificio, de modo que no requieran de paso por la zona privada del mismo. En el Alcázar de Sevilla, estos espacios llegan al súmmum de su refinamiento y complejidad arquitectónica con la presencia de un auténtico salón del trono con sofisticados accesos para salvaguardar la privacidad del monarca y de su casa.

Algunas de estas salas tienen también carácter de puntos de control territorial y de referentes lejanos del lugar donde reside la autoridad. En Astudillo y Tordesillas esto se logra a través de simples ventanas o balcones abiertos hacia el entorno. En Carmona este elemento adquiere una presencia mucho más potente al tratarse de una larga galería de balcones abiertos en la dirección en que se domina una mayor extensión de territorio y en donde su visión desde el exterior del alcázar toma mayor fuerza por la posición elevada que ocupa. Este esquema de galerías abiertas al exterior tendrá un seguimiento indiscutible en algunas de las obras de los Reyes Católicos, que habitaron este alcázar y que lo hicieron decorar con un motivo de clara intención legitimadora: la galería de retratos de reyes predecesores en el trono. Son los casos de la Aljafería de Zaragoza y del Alcázar de Sevilla en donde construyeron galerías-miradores con vistas sobre el entorno del palacio ${ }^{37}$, rompiendo de ese modo la introversión de estas construcciones.

Otra de las características es la presencia de espacios de alto simbolismo, especialmente los de planta centralizada como las qubbas. No debió haberla en Astudillo, tratándose de una residencia menor y en realidad propiedad de María de Padilla. Pero sí creemos que la hubo en Tordesillas, y aunque en modo más modesto, el Alcázar de Carmona tuvo una sala con bóveda de ocho paños de aspecto cupuliforme, ligada a las galerías-miradores y cuya presencia estaba enfatizada por una construcción más esmerada.

La portada del Cuarto Real del Alcázar de Sevilla ha conservado suficientes restos como para mostrarnos que estuvo ricamente policromada, sobresaliendo de un modo especial los dorados. No sabemos si las fachadas de los otros palacios tuvieron parecida ornamentación. Lo que no ofrece duda es que tal recurso constituía un modo de ostentación perfectamente visible para quien contemplara el palacio desde el exterior, que quedaba impresionado por la magnificencia del mismo inclinando su ánimo a reconocer el poder de quien lo habitaba. En este sentido, la portada del alcázar sevillano fue sin duda el elemento propagandístico más importante de cuantos utilizó Pedro I al servicio de su programa político ${ }^{38}$.

37 A. ALMAGRO, "La imagen de la Aljafería a través del tiempo. Evolución morfológica", A. BELTRÁN MARTÍNEZ (dir.), La Ajafería, Zaragoza, 1998, vol. II, p. 416.

38 El presente estudio se ha realizado en el marco del proyecto de investigación "La arquitectura residencial de al-Andalus: análisis tipológico, contexto urbano y sociológico: bases para la intervención patrimonial" (Proyecto I+D+i del Plan Nacional de Investigación Científica, HAR2011-29963). 